\title{
PRIN CE ÎŞI VA ÎNDREPTA UN TÂNĂR CALEA SA? (PSALMUL 118, 9A)
}

Motto: Si jeunesse savait ! si vieillesse pouvait !

(Grandville)

Alexandru Moldovan*

Abstract: If ancient writings can still convey something to the young generation, which is very familiar nowadays with all the discoveries of modern technology and which is 'dependent' on all these, then my approach will not be in vain. Just as the school years cannot be absent in the biography of a person, the 'compulsory' school bibliography cannot omit the Book of Proverbs, a jewel of the sapiential literature of the Old Testament. For the theology student, who is the first to have the chance to read these lines, they constitute an invitation to read a text which will help him know wisdom and learning and understand the meaning of the profound and witty words. But above all, it will help him understand justice, truth and the righteous judgment, and it will satisfy 'the thirst for meaning' that man has deeply inscribed in his being. If we usually say that wisdom is the prerogative of the white-haired or of old age, the Holy Scripture gives us many examples that contradict this 'rule', presenting young people whose pure and unblemished conscience opposes the opinion of the majority as a kind of protest against the superficiality, the recklessness and the flightiness of the vulgus that behaves mediocrely and totally devoid of judgmental spirit.

Keywords: Wisdom, the sapiential literature of the Old Testament, Solomon's Book of Proverbs, justice, the righteous judgment, superficiality, mediocrity, convenience, flightiness, youth.

* PhD, Assistant Professor, Faculty of Orthodox Theology, "1 Decembrie 1918" University, Alba Iulia, Romania, Last work: Christ and Caesar. A Neotestamentary Perspective, in vol. "The Church-State Relationship: from Constantine the Great to PostMaastricht Europe", Proceedings of 12-th International Symposium on Science, Theology and Arts (ISSTA 2013), vol. 1, Supplement of "Altarul Reîntregirii" Journal, Dumitru A Vanca, Mark Cherry, and Alin Albu (eds.), Alba Iulia, Reîntregirea Publishing House, 2013, p. 243-260. Contact: alexmoldovan@hotmail.com 


\section{Preliminarii}

Din Egipt a ieșit înțelepciunea pentru a ajunge în țara în care trăiesc: așa se exprima Wen-Amun sau Wen-Amon, un oficial al templului de la Karnak, exilat în Fenicia, în secolul al IX-lea î. Hr. Dacă Egiptul a fost leagănul genului literar numit sapiențial, gen care s-a păstrat până la noi în aproximativ cincisprezece texte vechi (între care unul, Înțelepciunea lui Amenhotep, a fost reluat și reelaborat în cartea Pildelor lui Solomon, 22, 17 - 23, 11), ea s-a afirmat și în Mesopotamia și în arealul siro-palestinian. La început înclinația spre înțelepciune și spre filozofie s-a manifestat în rândurile aristocrației și avea ca scop instruirea noilor generații de la casa regală, a scribilor și a intelectualilor de la curtea suveranului.

Metodele didactice folosite de dascălii timpurilor respective erau de tip experimental, practic și empiric. În general, se studiau cele trei relații sau raporturi fundamentale care aveau în centru omul: legătura sa cu divinitatea, cu aproapele și cu lumea creată. Pe lângă această deprindere nobilă și nobiliară s-a dezvoltat încă una de tip popular, care se exprima prin ziceri scurte cu caracter sapiențial, prin proverbe, prin ghicitori și era dedicată unui public mai larg, având în vedere formarea profesională, normele etice comune și viața socială cotidiană ${ }^{1}$. În ultimă instanță întrebarea fundamentală era aceea pe care înțeleptul biblic a formulat-o în următoarele cuvinte: $C e-i$ rămâne omului din toată osteneala lui cu care se trudește sub soare? (Eccl. 1, 3), iar răspunsul la ea, și astăzi, ca și atunci, este același: Deșertăciunea deșertăciunilor, toate sunt deșertăciune (Eccl.1 1, 2; $12,8)$. Și mai profund, întrebarea poate fi pusă astfel: Dacă totul este deșertăciune, merită viața să fie trăităa? ${ }^{2}$.

$\mathrm{Nu}$ ştiu dacă acestea sunt întrebări pe care și le-ar pune un tânăr. Nici înțeleptul biblic nu și-a pus această întrebare în tinerețea lui, pentru că atunci se gândea doar la iubire, dar și-a pus-o îndată ce

${ }^{1}$ L'Antico Testamento. Conoscerlo, leggerlo, viverlo. A cura di Gianfranco Ravasi, Milano, Edizioni San Paolo, 2013, p. 193.

2 Bruna Costacurta, Corso di Scritti Sapienziali e Salmi. Appunti della professoressa. Roma, Pontificia Università Gregoriana, 1998, p. 9. 
a atins pragul maturității (lucru care se întâmpla le vechii evrei cam pe la vârsta de 30 de ani).

Așadar, cu ce rămâne omul după toată truda lui de o viață? Întrebarea aceasta s-a pus mereu și astăzi revine în actualitate într-un cântec cu iz de manea foarte des fredonat de contemporanii noştri (printre ei și foarte mulți tineri): $\mathrm{Cu}$ ce m-am ales în viață ? și răspunsul pare să fie același: Ce-am băut, ce-am mâncat și cu ce am strâns în brațe. Cine a compus aceste versuri înțelege că omul este o ființă care caută sensul în toate, chiar și acolo unde nu e, căutare pe care noi astăzi o numim filozofică sau științifică și zice mai departe așa: Dă-i, Doamne, românului (am putea spune omului), dă-i mintea pățitului, poate că așa ar ști ce să ia bun de la viață; dă-ne mintea de pe urmă să ne meargă toate strună și să luăm ce-i mai bun în viață !

Dar să revenim la portretul și la chipul înțeleptului biblic pe care Scriptura îl creionează astfel:

„Şi i-a dat Dumnezeu lui Solomon pricepere și foarte multă înțelepciune și mărinimie ca nisipul de pe țărmul mării. Înțelepciunea lui Solomon era mai multă decât a tuturor celor din vechime și mai presus decât a tuturor înțelepților Egiptului; el era mai înțelept decât toți ceilalți oameni ... Solomon a rostit trei mii de proverbe, iar cântările lui au fost o mie și cinci. El a vorbit despre copaci, de la cedrii cei din Liban până până la isopul de pe ziduri; a vorbit și despre animale, despre păsări, despre târâtoare şi despre pești. La el veneau toate neamurile să-i asculte înțelepciunea, și el primea daruri de la toți regii pământului, din câți auziseră de înțelepciunea lui" (III Regi 5, 914).

Într-o operă deuterocanonică de la sfârșitul secolului I î. Hr., scrisă în limba greacă - e vorba de Cartea Înțelepciunii lui Solomon - autorul pune în gura înțeleptului rege Solomon aceste cuvinte semnificative pentru a indica amplul orizont al interesului sapiențial, interes pus în practică în cadrul științelor care se studiau la vremea aceea: Domnul 
„mi-a dat cunoașterea corectă a lucrurilor create, să știu plămada lumii şi vlaga din stihii, cum se sfârșește timpul după început și mijloc, și vremea-n du-te-vino, și vremile-n prefaceri, cum se rotește anul, cum astrele se mișcă, natura animalelor, deprinderile fiarelor, puterea unor duhuri şi gândurile oamenilor, şi felurimea plantelor şi leacul rădăcinilor; tot ce-i ascuns, precum și ce e vădit, am cunoscut, fiindcă înțelepciunea, ce meșterește totul, mi-a dat învățătură" (Înțelepciunea lui Solomon 7, 17-21).

Două au fost imboldurile care 1-au condus pe om în căutarea sapiențială: este vorba despre două viziuni asupra lumii care au avut o abordare și rezultate antitetice ${ }^{3}$. Pe de-o parte, a existat o abordare de factură optimistă, care 1-a condus spre alegeri pragmatice și utilitariste; omul a avut în vedere utilitatea imediată a lucrurilor și a urmărit avantajul și profitul personal din cunoașterea lumii înconjurătoare. În acest tip de abordare, important și decisiv era bunul simț comun, în timp ce contradicțiile și problemele vieții treceau în plan secund. Cei care s-au aplecat astfel asupra lumii înconjurătoare au văzut în aceasta o lege constantă, o lege pe care exegeții și comentatorii biblici au numit-o teoria sau legea retribuției divine $^{4}$. Potrivit acestei legi, orice delict sau abatere de la normele morale era pedepsit, iar practicării dreptăţii îi urma numaidecât un premiu sau o răsplată. Totul, însă, era sau se petrecea aici pe pământ. Acesta a fost un prim mod de a ordona realitatea înconjurătoare care, în realitate, era mult mai complexă și mai enigmatică. Această abordare a lumii sau această viziune asupra lumii care apare cu precădere în Cartea Pildelor sau a Proverbelor lui Solomon este reluată apoi într-o altă carte deuterocanonică mai târzie - e vorba de Cartea Înțelepciunii lui Isus, fiul lui Sirah - și e evidentă în atitudinea prietenilor lui Iov, care vin să-l mângâie în necazul său cu

\footnotetext{
${ }^{3}$ L'Antico Testamento. Conoscerlo, leggerlo, viverlo. p. 172.

${ }^{4}$ Nuovo Grande Commentario Biblico. Terza Edizione. Raymond E. Brown, Joseph A. Fitzmyer, Roland E. Murphy, (eds). A cura di Flavio dalla Vecchia, Giuseppe Segalla e Marco Vironda. Brescia, Editrice Queriniana, 1997, p. 585.
} 
convingerea că cel rău va fi la sfârșit pedepsit, răul va fi biruit, în timp ce binele va fi răsplătit și va triumfa ${ }^{5}$.

$\mathrm{O}$ a doua linie de abordare a realității înconjurătoare, mult mai sofisticată și mai puțin dogmatică, întrucât refuză sau respinge o interpretare idilică a realității, și-a îndreptat atenția asupra contradicțiilor care sunt în istorie şi care strică ordinea presupusă și susținută de teoria retribuției divine. Oare nu ne-a demonstrat viața aceasta că scena istoriei umane este dominată de cei răi, violenți și nedrepți? Gândul nostru aleargă în mod spontan spre două cărți cu caracter sapiențial, foarte provocatoare, dificile, incomode, care au ridicat întrebări a căror răspuns cu anevoie poate fi găsit - e vorba de Cartea Ecclesiastul și de Cartea Iov - cărți care reprezintă expresia cea mai fidelă a acestui tip de abordare a realității, mult mai dramatic și mai problematic ${ }^{6}$.

Prin intermediul acestei diferențieri, care simplifică puțin lucrurile, între abordarea optimistă și cea pesimistă, putem cataloga mai ușor cărțile sapiențiale ale Sfintei Scripturi, așezând într-o parte cărțile: Pildele lui Solomon, Înțelepciunea lui Isus, fiul lui Sirah și Înțelepciunea lui Solomon (aceasta din urmă deschizându-se spre un orizont nou și vorbind despre o retribuție dincolo de mormânt). De cealaltă parte avem dipticul Iov și Ecclesiastul, opere diferite între ele la nivel idealist, însă amândouă hotărâte să ne semnaleze criza modelului sapiențial tradiţional. Trebuie să amintim faptul că cele două abordări sau cele două concepții de viață descrise în aceste cărți apar și în celelalte cărți ale Bibliei, dincolo de perimetrul literaturii sapiențiale ${ }^{7}$.

O identitate și un caracter aparte au Cartea Psalmilor și Cântarea Cântărilor (și ele încadrate în lista cărților cu caracter sapiențial): Psaltirea este cartea de rugăciuni a lui Israel și a Bisericii deopotrivă și în cuprinsul ei întâlnim o gamă largă de genuri literare și de tipuri de psalmi, în timp ce Cântarea Cântărilor este un poem

\footnotetext{
${ }^{5}$ L'Antico Testamento. Conoscerlo, leggerlo, viverlo, p. 172.

${ }^{6}$ Ibidem.

${ }^{7}$ Nuovo Grande Commentario Biblico, în op. cit., p. 585-586.
} 
simbolic dedicat iubirii dintre Iahve și poporul Său sau dintre Dumnezeu și sufletul uman ${ }^{8}$.

Este semnificativ faptul că aceste opere și aproape toate cărțile care alcătuiesc așa-numita literatură sapiențială biblică sunt scrise în versuri, stilul lor poetic fiind unul foarte elevat, așa cum este, spre exemplu, cazul cărții Iov. Acest fapt i-a determinat pe unii comentatori biblici să le numească didactico-poetice. Exegeza biblică a analizat mult aceste pagini, căutând să cunoască stilul poeziei ebraice. Acest tip de poezie este departe de a fi rodul unui amatorism mai mult sau mai puțin izbutit; ea vădește o anumită știință sau o anumită tehnică a versificației, deloc lipsită de rafinament. Principiul fundamental al compoziției poetice ebraice era paralelismul stihurilor, adică, în fapt, paralelism al gândirii în două sau trei versuri succesive; ideea din primul vers fiind reluată în al doilea vers care, după caz, o repetă prin cuvinte asemănătoare, o neagă sau o îmbogățește 9 . Paralelismul este un mod simplu, dar foarte eficace prin care autorul biblic reia și ne propune aceeași temă din unghiuri diferite sau chiar opuse, cu rezultate interesante și adesea paradoxale, cum este cazul acestui proverb: Nu-i răspunde nebunului după nebunia lui de teamă să nu-i devii asemenea, ci răspunde-i nebunului după nebunia lui, ca nu cumva lui să i se pară că e ințelept (Pildele lui Solomon 26, 4-5).

Viziunea de ansamblu a literaturii sapiențiale biblice caută revelația sau descoperirea dumnezeiască nu atât în marile evenimente ale istoriei umane (așa cum este cazul literaturii profetice), ci, mai degrabă, în lumea creată, în cadrul societății umane, în prozaicul cotidian, în persoanele umane. Potrivit înțeleptului biblic, epifaniile sau teofaniile se cuprind sau sunt ascunse în aceste realităţi cotidiene. Înțelepciunea, în mentalitatea ebraică, nu este doar o calitate a minții

\footnotetext{
${ }^{8}$ L'Antico Testamento. Conoscerlo, leggerlo, viverlo. p. 173.

${ }^{9}$ Biblia sau Sfânta Scriptură, versiunea diortosită după Septuaginta, redactată și adnotată de Bartolomeu Valeriu Anania, Arhiepiscopul Clujului. Introducere la Psalmi. București, Edit. Institutului Biblic și de Misiune al Bisericii Ortodoxe Române, 2001, p. 614.
} 
omenești; în forma ei ideală, supremă, e o calitate a gândirii divine care a adus la existență tot ceea ce există prin ințelepciune ${ }^{10}$.

Aghiograful a personificat această înțelepciune într-o figură feminină și a așezat-o lângă Creator ca pe o expresie a operei Sale creatoare: Cât de minunate sunt lucrurile Tale, Doamne, pe toate intru ințelepciune le-ai făcut (Ps. 103, 24). Acesta a fost modul său de a ne arăta proiectul armonios pe care Dumnezeu 1-a avut în minte și 1-a adus la ființă în actul creației. Astfel, înțelepciunea se prezintă pe sine ca pe un arhitect desăvârşit care a proiectat lumea creată și ca pe o tânără femeie care dansează înaintea lui Dumnezeu ${ }^{11}$ :

\begin{abstract}
„Domnul m-a zidit ca început al căilor Sale spre lucrurile Lui; întrunceput, mai înainte de veci $\mathrm{m}$-a întemeiat, mai înainte de a fi durat pământul și mai înainte de a fi făcut adâncurile, mai înainte ca izvoarele apelor să fi țâșnit, mai înainte ca munții să fi fost sădiți și mai înainte decât toate dealurile, El pe mine m-a născut... Când Domnul pregătea cerul, eu cu El eram; și când Şi-a aşezat tronul deasupra vânturilor... şi când a întărit temeliile pământului eu lângă El eram, una fiind în lucrare, eu eram aceea în care El Se bucura și-n toate zilele necontenit mă veseleam de fața Lui”" (Pildele lui Solomon 8, 22-30).
\end{abstract}

Înțelepciunea divină, creatoare și mântuitoare, devine înțelepciune omenească prezentă în lucrările omului și în rațiunea sa. Înţelepciunea divină este un

„duh deștept și sfânt, fără pereche (adică unic), cu multe căi, subțire (adică subtil, de mare finețe), pătrunzător și sprinten și fără nicio pată și limpede, statornic și iubitor de bine, gata oricând (adică prompt), năvalnic și binefăcător și iubitor de oameni, de neclintit, temeinic, lipsit

${ }^{10}$ L'Antico Testamento. Conoscerlo, leggerlo, viverlo. p. 174.

11 Bruna Costacurta, Corso di Scritti Sapienziali e Salmi. Appunti della professoressa. Roma, Pontificia Università Gregoriana, 1998, p. 15-24; L'Antico Testamento. Conoscerlo, leggerlo, viverlo. p. 174-175; R. E. Murphy, CBQ 48 [1986], p. 456-460; R. E. Murphy, L'albero della vita. Una esplorazione della letteratura sapienziale biblica, Brescia, Editrice Queriniana, 1993, p. 188-200. Titlul original al operei: The Tree of Life. An Exploration of Biblical Wisdom Literature (The Anchor Bible Reference Library). 
de îngrijorări; el, cel ce poate totul și peste tot veghează, străbate ca un fulger prin duhurile toate cele deștepte, limpezi și oricât de subțiri” (Înțelepciunea lui Solomon 7, 22-23).

Pentru a o descrie, aghiograful folosește douăzeci și unu de adjective (3 x 7), fapt care în simbolistica cifrelor indică deplinătatea și perfecțiunea ${ }^{12}$.

Înțelepciunea se mișcă mult mai repede decât orice: străbate și pătrunde prin toate, pretutindeni. Înțelepciunea este un suflu al puterii lui Dumnezeu (Pilde 7, 24-25). Ea intră în realitatea umană și în cea cosmică. Astfel, și în cazul înțelepciunii divine putem vorbi de un fel de intrupare și acesta va fi motivul pentru care, în Noul Testament, ea va fi reluată și interpretată în cheie hristologică în texte precum: 1 Corinteni 1, 24-30; Efeseni 3, 8-10 și Coloseni 1, 15 17.

\section{Titlul cărții Pildelor și locul ei în canonul Vechiului Testament}

Cartea Pildelor sau a Proverbelor lui Solomon a fost pentru multă vreme trecută cu vederea de exegeții și comentatorii Sfintei Scripturi şi numai începând cu a doua jumătate a secolului trecut asistăm la o înmulțire a studiilor pe marginea ei. Prin formă și prin conţinut, cartea Pildelor lui Solomon este considerată cel mai reprezentativ rezultat al tradiției sapiențiale ${ }^{13}$.

Cartea aceasta ocupă locul al treilea, după Cartea Iov și Cartea Psalmilor, în lista cărților didactico-poetice, iar în canonul ebraic ea apare în colecția Scrierile (Ketubìm), adică în a treia parte a Sfintei Scripturi, după Lege (Torà) și Profeți (Nebi'ìm).

În limba ebraică titlul acestei cărți este Mishlè Shelomò (Proverbele lui Solomon). Termenul mishlè este pluralul cuvântului mashàl, care devine în limba latină proverbiae (pluralul cuvântului

${ }^{12}$ L'Antico Testamento. Conoscerlo, leggerlo, viverlo, în op. cit., p. 174-175.

${ }^{13}$ L'Antico Testamento. Conoscerlo, leggerlo, viverlo, în op. cit., p. 193. 
proverbium) și înseamnă nu numai proverb, ci și zicere, sentință, maximă, cugetare, parimie, pildă sau învățătură $\breve{a}^{14}$.

Solomon a devenit prototipul înțeleptului prin excelență, iar Cartea a Treia a Regilor ne oferă un exemplu sugestiv de înțelepciune: textul în care două femei își dispută dreptul de maternitate asupra unui copil nou-născut și i se adresează înțeleptului rege pentru a rezolva disputa lor (3 Regi 3, 16-28).

Pe lângă acest text, din 3 Regi 5, 12 aflăm că regele Solomon a rostit trei mii de proverbe, iar cântările lui au fost o mie și cinci. $\mathrm{Nu}$ e întâmplător faptul că, pe lângă Cartea Proverbelor, tradiția ebraică i-a atribut lui Solomon Cântarea Cântărilor, iar Ecclesiastul și Cartea Înțelepciunii au o referire indirectă la persoana $\mathrm{sa}^{15}$.

\section{1. Structura și aspectele literare ale cărții}

Exegeții și comentatorii Sfintei Scripturi au împărțit această carte în șapte părți, gândindu-se, foarte probabil, la cele șapte coloane pe care înțelepciunea și-a zidit și și-a întărit casa (Pilde 9, 1). Numărul șapte este simbolul perfecțiunii, iar în textul de faţă el indică garanția durabilității și a statorniciei.

Critica literară a scos în evidență eterogenitatea textelor aflate în cuprinsul cărții și caracterul ei compozit.

Prologului cărții (Pilde 1, 1-7) îi urmează primele nouă capitole în care cititorului îi sunt oferite mai multe criterii care-l pot conduce spre înțelepciune. Textele despre femeia străinăa, descrisă de mai multe ori în capitolele 1-9, și cele despre Înțelepciune, par să facă trimitere la o altă figură feminină, la femeia virtuoasă din

${ }^{14}$ Nuovo Grande Commentario Biblico, în op. cit., p. 591-593; M. Gilbert - J. N. Aletti, La sapienza e Gesù Cristo. Torino, 1982; G. Segalla, Le figure mediatrici di Israele tra il III e il I secolo a. C. La storia di Israele tra guida sapienziale e attrazione escatologica, in G.L. Prato (ed.), Israele alla ricerca di identità tra il III sec. a.C. e il I sec. d.C., in: „RStB” (1989/1) p. 13-65.

${ }^{15}$ L'Antico Testamento. Conoscerlo, leggerlo, viverlo, în op. cit., p. 194. 
capitolul 31 al cărții, formând în acest fel un tablou literar sau un cadru general din epoca post-exilică ${ }^{16}$.

Secțiunile din partea centrală a cărții cuprind avertismente exprimate sub formă de sentințe binare construite din două stihuri care abordează, fără a urmări un scenariu foarte precis, teme sapiențiale diferite, adică toată gama moralității omului și a vieții sociale, totul fiind cumpănit prin suprema virtute a înțelepciunii, o înțelepciune care își are izvorul în Dumnezeu, care se învață și se transmite prin inițiere directă și al cărei preț se situează dincolo de orice estimare. Așa sunt evaluate nu numai faptele omului, ci și consecințele lor, fericirea dreptului și pedepsele ce vin asupra celui nedrept, familia ca instituție fundamentală a umanității, relațiile dintre orgoliu și smerenie, dintre minciună și adevăr, lașitate și curaj, viclenie şi sinceritate, lene și hărnicie, înșelăciune şi necinste; nu este ocolită nici viața cetății, cu accente speciale pe instituția regalității. Mitropolitul Bartolomeu Anania a comparat această carte cu o pajiște cu flori multe și felurite, din care cititorul (tânărul) ișsi poate culege aromele care-i produc plăcere ${ }^{17}$.

Dacă e adevărat că Pildele sau Proverbele lui Solomon reprezintă exprimarea tipică a tradiției sapiențiale, asta se datorează formei literare care stă la baza alcătuirii acestei cărți. Substantivul mashàl, așa cum am văzut, are o gamă largă de semnificații: zicere populară, proverb, sentință ințeleaptă, sfat înțelept (pentru o viață mai bună), parabolă sau pildă. Așadar, nu numai o zicere scurtă, ci o întreagă poveste care urmărește să-i transmită cititorului sau ascultătorului un mesaj ${ }^{18}$.

Pilda sau proverbul este un gen literar frecvent în paginile Sfintei Scripturi; apare și în alte texte din Vechiul Testament (cf. 1

\footnotetext{
${ }^{16}$ Nuovo Grande Commentario Biblico, în op. cit., p. 592.

${ }^{17}$ Biblia sau Sfânta Scriptură. Versiunea diortosită după Septuaginta, redactată și adnotată de Bartolomeu Valeriu Anania, Arhiepiscopul Clujului. Introducere la Proverbele lui Solomon. București, Edit. Institutului Biblic și de Misiune al Bisericii Ortodoxe Române, 2001, p. 787.

18 Bruna Costacurta, Corso di Scritti Sapienziali e Salmi. Appunti della professoressa. Roma, Pontificia Università Gregoriana, 1998, p. 9.
} 
Regi 19, 24; 24, 14; Ieremia 23,28; 31, 29; Iezechiel 18, 2), dar și în vorbirea Mântuitorului Hristos. Ea se compune din unele elemente care sunt de obicei întâlnite și în alte genuri literare cum ar fi: enigma, fabula, alegoria, poemul, aforismul, cugetarea, maxima sau discursul sapiențial.

Pilda sau proverbul are marele avantaj în înțelegerea conținutului ei prin faptul că poate fi foarte ușor memorată, datorită stilului eficace, ajutându-ne să cuprindem într-o frază scurtă, ca întro rugăciune, adevărul esențial pe care vrea să-1 transmită ${ }^{19}$.

Așa cum am văzut, principiul fundamental al compoziției poetice ebraice era paralelismul stihurilor, adică paralelism al gândirii în două sau trei versuri succesive; ideea din primul vers fiind reluată în al doilea vers care, după caz, o repetă cu cuvinte asemănătoare, o neagă sau o îmbogățește. Avem în poezia ebraică paralelismul sinonimic (ideea din primul vers este reluată în al doilea vers prin sinonime: Cerurile povestesc slava lui Dumnezeu și facerea mâinilor Lui o vestește tăria (Ps. 18, 1); avem apoi paralelismul antitetic (ideea din primul vers este reluată în al doilea vers în formă antitetică: Cel care-l înșală pe sărac își sporește averea, dar dacă-i dă bogatului, și-o micșorează (Pilde 22, 16), dar avem și paralelismul sintetic (în sensul în care al doilea vers adaugă ceva celui dintâi pentru a-i spori înțelesul): Ceartă-l pe fiul tău și el îți va da odihnă și frumusețe îi va da sufletului tău (Pilde 29, 17).

\section{2. Linii teologice fundamentale}

Înțelepciunea personificată. În cuprinsul cărții, cititorul avizat va întâlni și va identifica o înțelepciune scrisă cu literă minusculă (în texte precum Pilde $1,2.7 ; 2,6$ ) și o înțelepciune scrisă cu literă majusculă ca în următoarele texte: Înțelepciunea prin răspânti își inalță glasul și pe ulițe vorbește deschis, pe coamele zidurilor ișsi face vestirea, la porțile celor puternici se așază și la porțile cetății cu indrăznire grăiește (Pilde 1, 20-21) sau

${ }^{19}$ L'Antico Testamento. Conoscerlo, leggerlo, viverlo, în op. cit., p. 195. 
Ințelepciunea și-a zidit sieși casă și pe șapte stâlpi a întărit-o (Pilde $9,1)$, texte pe care exegeții le-au numit ințelepciunea personificat ${ }^{20}$. Cea dintâi exprimă arta de a trăi potrivit preceptelor înțelepților și potrivit poruncilor lui Dumnezeu; cea de-a doua se prezintă ca o femeie virtuoasă care mediază raportul dintre Dumnezeu și oameni, punându-se în strânsă legătură cu ambii parteneri ai dialogului. Această Ințelepciune nu e în mod simplu unul din multele atribute ale lui Dumnezeu, cum ar fi: dreptatea, sfințenia, atotștiința, atemporalitatea sau aspațialitatea; această Ințelepciune nu poate fi redusă la o figură retorică, deoarece forța cu care se exprimă și cu care se impune în textul cărții ne permite să identificăm un subiect care acționează în nume și pe cont propriu, conștient de propria identitate până în punctul în care se oferă ca o realitate care ar putea fi invocată sau chemată pe nume ${ }^{21}$ : Veniți, fiilor, ascultați-mă pe mine; frica Domnului vă voi învăța (Ps. 33,11$)$.

Înțelepciunea care vine de la Domnul. Înțelepciunea pe care ne-o prezintă cartea își are sursa sau izvorul în Dumnezeu: Frica de Domnul este începutul înțelepciunii (Pilde 1, 7; 9, 10). În Cartea Proverbelor din frica de Domnul derivă însăși viața omului Frica de Domnul adaugă zile (Pilde 10, 28) sau Porunca Domnului e izvor de viață (Pilde 14,27) sau Spre viață îi este omului frica de Dumnezeu (Pilde 19, 23a). Din frica de Dumnezeu provine și smerenia sau modestia, dar și învățătura: Iscusitul (Ințeleptul), văzându-l pe omul rău că rău se chinuiește, scoate el însuși o invvățătură, dar cei nepricepuți trec mai departe spre paguba lor (Pilde 22, 3). Frica de Domnul îi procură omului și pacea sufletească care se naște din absența invidiei: Inima ta să nu-i pizmuiască pe păcătoși, ci în toată vremea fii în frica Domnului (Pilde 23, 17).

\footnotetext{
${ }^{20}$ Nuovo Grande Commentario Biblico, op. cit., p. 593. R. E. Murphy, L'albero della vita. Una esplorazione della letteratura sapienziale biblica, în op. cit., p. 11 .

${ }^{21}$ Gerhard von Rad, La sapienza in Israele, Torino, Marietti, 1975, p. 75-100; Nuovo Grande Commentario Biblico, în op. cit., p. 592-593; Bruna Costacurta, Corso di Scritti Sapienziali e Salmi, op. cit., p. 10-11. Maurice Gilbert, La Sapienza del cielo, Cinisello Balsamo, 2005, p. 17-58.
} 
În textul din Pilde 2, 5 frica de Domnul este pusă în paralel cu cunoașterea Domnului. De fapt, la cunoașterea Domnului ajunge cel ce se teme de Domnul. Prin expresia frica de Domnul se exprimă un concept pozitiv care-i așază într-o poziție corectă pe cei care caută înțelepciunea și nu se închid în autosuficiență: Nădăjduiește cu toată inima în Dumnezeu, iar cu înțelepciunea ta nu te semeți (Pilde 3, 5).

Pe această linie hermeneutică nu putem să nu constatăm că cuvintele înțeleptului din Pilde cap. 1-9 sunt încărcate cu rezonanțe biblice care fac trimitere la texte legislative vechi precum textul din Ieșire cap. 20; Deuteronom cap. 4 și 6. Aceste trimiteri biblice conferă autoritate canonică instrucțiunilor care deschid - ca un preambul - întreaga carte a Proverbelor lui Solomon. Într-o epocă istorică (foarte probabil în epoca persană târzie, secolele V-IV î. Hr.) în care par să-i lipsească lui Israel două instituții fundamentale preoția și profeția - sau dacă existau nu-și mai exercitau cum se cuvine rolul lor în popor, așa cum au făcut-o în epocile anterioare, cuvintele înțeleptului suplinesc acest gol, fac față nevoilor oamenilor, actualizând cuvântul lui Dumnezeu prin intermediul învățătorilor ${ }^{22}$.

Tovărășiile drepte. În cuprinsul cărții Proverbelor nu există nici o urmă a ideii de determinism moral. Înțelepciunea se adresează tuturor oamenilor, deci nu doar unei elite. Doamna Înțelepciune se adresează deopotrivă înțelepților și nepricepuților și îi invită la pocăință. Cei din urmă, neînțelepții, novicii, începătorii, cei care abia au început să descopere calea înțelepciunii, sunt prăzi ușoare pentru cei rău intenţionați ${ }^{23}$. La o lectură mai atentă, cititorul poate descoperi tipologia comportamentală a celui arogant, purtarea obraznică și sfidătoare și mândria disprețuitoare a nebunului care în nebunia lui a zis: $N u$ este Dumnezeu! (Ps. 52, 1a). Cel mândru, arogantul, este descris astfel: Un om îndrăzneț și încrezut și obraznic se cheamă ciumă, iar cel ce ține minte răul e un nelegiuit (Pilde 21, 24). Înțeleptul știe că cuvântul rău, păgubos și nimicitor al arogantului arată ca ineficace, mai mult, dăunătoare, orice încercare

${ }^{22}$ L'Antico Testamento. Conoscerlo, leggerlo, viverlo, în op. cit., p. 196-197.

${ }^{23}$ Ibidem. 
de corecție: Cel care-i ceartă pe cei răi își va atrage dispreț, iar cel ce-l mustră pe cel necurat se necinstește pe sine (Pilde 9,7).

Din sfaturile și din învățăturile înțeleptului se deduce dorința lui de a-1 pune în gardă pe ucenic față de tovărășiile rele care se concretizează prin unele figuri negative ${ }^{24}$. În primul rând, sunt înfierați și condamnați sever păcătoşii. Termenul este generic în literatura sapiențială și în paginile Sfintei Scripturi, însă în pericopa din Pilde 1, 10-19 el face trimitere la o categorie precisă, la un grup de oameni dedicat, în mod obișnuit, delincvenței. Tânărul este îndemnat să nu-și facă din astfel de oameni tovarăşi de drum (Pilde 1, 15). Aceștia îl îmbrobodesc pe cel tânăr și naiv, promițându-i un câștig rapid și ieftin, rod al răpirilor, al violenței și al furtului.

Alături de păcătoşi, înțeleptul trasează fizionomia nelegiuiților sau a necredincioșilor, oameni periculoși, incapabili să înțeleagă sau să priceapă binele ${ }^{25}$ : Oamenii răi nu înțeleg judecata; dar cei ce-L caută pe Domnul vor înțelege totul (Pilde 28, 5). Nelegiuiții poftesc răul: Sufletul necredinciosului poftește răul (Pilde 21, 10); răul se vede din cuvintele și din dorințele lor, dar și din conduita lor inclinată spre lenevire și spre ceartă: Omul rău scornește certuri (Pilde 17, 11).

Femeia străină. O figură fatală în Cartea Pildelor lui Solomon este femeia străină sau adulteră și este descrisă în texte diferite (cf. Pilde 5, 1-23; 6, 24-34; 7, 5-26; 9, 13-20). Aceasta îl seduce prin farmecul vorbelor și prin purtare obraznică pe cel lipsit de minte, atrăgându-1 în casa ei din care, ca și din iad, nu există scăpare. Între numeroasele interpretări ${ }^{26}$ care s-au dat acestei figuri misterioase (sunt exegeți care au văzut în ea o trimitere la o divinitate sau la o prostituată sacră, la o străină ca outsider, ca una care răstoarnă regulile și principiile societății prin conduita sa libertină), o atenție specială merită aceea care a văzut în această figură o trimitere

\footnotetext{
${ }^{24}$ Bruna Costacurta, Corso di Scritti Sapienziali e Salmi, în op. cit., p. 11-15.

${ }^{25}$ L'Antico Testamento. Conoscerlo, leggerlo, viverlo, în op. cit., p. 198.

${ }^{26}$ G. Bellia - A. Passaro (a cura di), Libro dei Proverbi. Tradizione, redazione, teologia. Casale Monferrato, Edizione Piemme, 1999, p. 55-63. Nuovo Grande Commentario Biblico, în op. cit., p. 592-593.
} 
la textele din Ezdra 9-10, la un timp în care s-a recurs la repudierea soțiilor străine, din cel puțin două motive: pentru rațiuni etnice, întrucât nu aparţineau poporului ales și din raţiuni economice (endogamia consimțind ca proprietatea și averea materială să rămână în interiorul aceluiași clan).

E important să subliniem faptul că din cele zece sfaturi împărtăşite de părinții (în mod special de tată, dar și de mamă) copiilor lor, reiese faptul că pericolul femeii străine nu constă atât în frumusețea ei, cât în cuvintele ei mai amare decât fierea și mai ascuțite decât sabia cu două tăișuri (Pilde 5, 4), deși la început sunt dulci ca mierea și îndulcesc gâtlejul. Aghiograful indică astfel un contrast evident între cuvintele vieții rostite de cel înțelept, dar și de Înțelepciunea personificată și cuvintele aducătoare de moarte rostite de femeia străină ${ }^{27}$.

Raportul cu femeile, cu ceilalți oameni și cu Dumnezeu. Tânărul trebuie să deosebească relațiile care-1 conduc spre bine, dar și pe cele care-1 conduc la moarte. Acestea din urmă, chiar dacă sunt atrăgătoare și ademenitoare, întrucât promit o delectare și o plăcere imediată, economică (împărțirea prăzii cu păcătoșii și cu nelegiuiții) și fizică (satisfacerea propriilor instincte săvârșind adulter și ignorând orice lege sau regulă socială și religioasă), ele se dovedesc a fi dezastruoase prin consecințele lor. Cel nepriceput trebuie să învețe să adopte atitudinea cea mai potrivită pentru a dobândi adevărata bunăstare psihologică, socială și religioasă ${ }^{28}$. Înțeleptul este conștient de corespondența care există între fapta sa și credința sa, deoarece omul care apasă pe cel sărac îl mânie pe cel ce l-a făcut, dar cel care-l miluiește pe sărac, acela Îl cinstește (Pilde 14, $31)$.

Una dintre cărțile Sfintei Scripturi - este vorba de Istoria Susanei - ne prezintă un tânăr care, prin prospețimea spiritului său, contrazice opinia și atitudinea gloatei, care se manifestă uneori

\footnotetext{
${ }^{27}$ L'Antico Testamento. Conoscerlo, leggerlo, viverlo, în op. cit., p. 198-199.

${ }^{28}$ Bruna Costacurta, Corso di Scritti Sapienziali e Salmi, în op. cit., p. 13-16; L'Antico Testamento, în op. cit., p. 199; Nuovo Grande Commentario Biblico, op. cit., p. 593.
} 
inconsecvent și total lipsită de judecată. Istoria Susanei este povestea unei femei tinere și curate, acuzată de adulter de către doi bătrâni libidinoși și imorali, care a fost salvată de la moarte nedreaptă de către tânărul Daniel.

Mai multe elemente din cuprinsul istorisirii au contribuit la succesul acestei scrieri: argumentul în sine în primul rând, dramatismul istorisirii și finalul fericit, care marchează triumful inocenței, al nevinovăției și al binelui, descrierea ironică pe care autorul o face celor doi bătrâni imorali, procesul rușinii la care sunt supuși cei doi și figura tânărului Daniel care salvează situația cu ajutorul unui procedeu juridic foarte ingenios, adică printr-un procedeu tipic într-o pledoarie avocățească, spre a descoperi și exploata eventualele contradicții între depozițiile martorilor. Întreaga expunere este pe fondul unei ințelepciuni populare dar și cultivate (cum este cea din Cartea Pildelor lui Solomon) și în stilul psalmilor. Povestea se petrece în mijlocul unei comunități de Evrei din Babilon, mai precis, în casa unui om înstărit, pe nume Ioachim, și a soției sale, Susana, fiica lui Hilchia, o femeie foarte frumoasă, de mare gingășie și mândră la vedere, dar și cu frică de Dumnezeu, pentru că părinții ei au avut grijă s-o crească așa cum se cuvine, după Legea lui Moise.

În acest scenariu anonim se desfăşoară un eveniment care va deveni proverbial. Doi bătrâni, aleși de respectiva comunitate, sunt rânduiți să exercite puterea judecătorească peste pricinile ivite între Evrei, iar judecata lor se desfășura în casa înstăritului Ioachim. Autorul îi descrie într-un mod cât se poate de negativ: judecata lor era mereu strâmbă, învinuiau nevinovați și eliberau pe cei vinovați, deci nu se remarcau prin respect față de justiție; erau nerușinați și libidinoși, căci s-au aprins de poftă asupra unei femei măritate pe care, neputând s-o corupă, au acuzat-o de imoralitate, iar în cele din urmă vor fi condamnați, expuși oprobriului public și omorâți ${ }^{29}$.

${ }^{29}$ I Profeti, traduzione e commento di L. Alonso Schökel e J. L. Sicre Diaz, Edizione italiana a cura di Gianfranco Ravasi, Terza Edizione, Roma, Edizioni Borla, 1996, p. 1491-1492. 
Doi iluştri consilieri din sfatul bătrânilor, doi bătrâni încă verzi, doi bătrâni îndrăgostiți ca doi flăcăi, se joacă de-a v-ați ascunselea prin grădina lui Ioachim, urmărind să-și satisfacă poftele prin priviri indiscrete printre zăbrele. Autorul și-a ales bine personajele, având evident o intenție critică, satirizând abuzurile de putere existente în comunitățile evreiești din Babilon. Fiindcă se vorbește peste tot în cadrul istorisirii de Iudei, trebuie să spunem că e vorba de o critică venită din interior, nu din afară, însă în acest scenariu s-ar putea regăsi foarte bine și alți conducători lipsiți de scrupule, care vor să profite de o femeie, dezonorând-o, oameni fără caracter și slabi, care se răzbună pe oricine rezistă capriciilor și intențiilor lor josnice și ticăloase.

De cealaltă parte, Susana reprezintă modelul feminin perfect, un ideal de fidelitate conjugală și de încredere în Dumnezeu, Care vede, știe și cunoaște calea drepților! Pentru calitățile ei, și potrivit tradiției biblice, această femeie ar putea reprezenta perfect comunitatea evreiască, fidelă Dumnezeului ei până la sacrificiu. Alte puteri și alte forțe o admiră și o râvnesc, îi solicită favorurile, o amenință cu moartea, iar ea trebuie să suporte abuzul și să depășească proba sau momentul de încercare.

Povestea se desfășoară într-o grădină desemnată prin cuvântul grecesc parádeisos (adică rai); aici stă la pândă ispititorul, cunoscătorul binelui și răului, al vieții și al morții, care, neputându-și ademeni sau amăgi victima, recurge la amenințare. Simpatia autorului pentru această tânără se manifestă limpede prin descrierea pe care i-o face: Susana e bogată, frumoasă, cinstită și cu frică de Dumnezeu; în viziunea lui, această tânără trebuie să atragă în jurul ei simpatia și interesul cititorilor Iudei, care nu trebuie să condamne atât de ușor chipul femeii. Renumele sau bunul nume al comunității e la fel de important, în ochii Domnului, ca și fidelitatea față de El.

Daniel este personajul care evocă puternic figura tânărului Samuel. Pentru vârsta lui fragedă, el se află într-un contrast izbitor cu bătrânii din poveste și astfel întruchipează un motiv literar pe care 1am mai întâlnit în paginile Sfintei Scripturi: outsider-ul, care aparent n-are nicio șansă, se impune înaintea favoritului. Vârsta tânără poartă 
cu ea stigmatele lipsei de putere și de autoritate, însă tocmai pentru aceste motive Dumnezeu o preferă și o alege, pentru ca tânărul să-și împlinească destinul propriului său nume: numele Daniel însemnând judecata lui Dumnezeu. Și Dumnezeu îl arată pe tânărul Daniel consilier bătrân! Strigătul tânărului traversează gloata ca un fel de protest împotriva perversiunii unora și împotriva superficialității, a ușurinței, a nesocotinței și a inconstanței altora: Nevinovat sunt eu de sângele acesta!. Cu alte cuvinte: Deși sunt cu voi, eu refuz să mă fac părtaș la crima voastră ! Glasul sau vocea tânărului Daniel e profetică și e îndreptată împotriva unor lideri a căror opinie și judecată păreau a fi de necontestat, dar și împotriva unei gloate care se manifestă superficial și total lipsită de spirit de judecată sau, poate, indiferentă și aservită sus-pușilor. Tânărul exprimă o judecată dreaptă - de viață şi de moarte - pe care comunitatea trebuie să o ratifice. El reprezintă o conștiință proaspătă, curată, nepătată, iar prin intermediul conștiinței lui, Dumnezeu ia din nou în stăpânire pe poporul Său ${ }^{30}$.

\section{În loc de concluzii...}

Cartea Pildelor lui Solomon cuprinde sfaturi, îndemnuri și porunci. Chiar dacă ele pot avea același conținut, totuși se diferențiază, se deosebesc, prin caracterul lor. Oricine poate să-mi dea un sfat, iar eu sunt liber să-1 primesc sau să-1 refuz; oricine poate să-mi dea un îndemn, dar nu oricine poate să-mi dea $o$ poruncă sau un ordin. Porunca are un caracter special, deoarece o poruncă înseamnă autoritate asupra mea. Autoritatea reprezintă un drept, o putere, o împuternicire de a comanda, de a da dispoziții sau de a impune cuiva ascultare ${ }^{31}$. Ascultarea de poruncile Domnului are drept consecință răsplătirea din partea autorității lui Dumnezeu, iar neascultarea de poruncile Sale atrage după sine pedeapsa. $\mathrm{Cu}$ sfaturile putem jongla, în sensul că le putem ignora; cu îndemnurile

\footnotetext{
${ }^{30}$ Ibidem .

${ }^{31}$ Autoritate, autorității, s. f. https://dexonline.ro/definitie/autoritate. (accesat la data de 18.04.2016)
} 
mai putem călca pe-alături; cu sfaturile și cu îndemnurile ne putem juca de-a ascultarea, dar nu putem face acest lucru cu poruncile lui Dumnezeu, pentru că în cazul poruncilor ne confruntăm cu autoritatea Lui. De aceea se spune în această carte: Cel ce nu ia în seamă cuvântul (lui Dumnezeu) este dat pierzării, iar cel ce se teme de porunca Lui este răsplătit (Pilde 13, 13), iar în alt loc se spune: Frica de Dumnezeu duce la viaţă (Pilde 19, 23a) sau Cel ce ia seama la poruncă iși păstrează sufletul său, iar cel ce disprețiește cuvântul (Domnului) va muri (Pilde 19, 16). Prin urmare, porunca lui Dumnezeu este expresia cea mai fidelă a autorității Lui.

În Prima Carte a lui Ezdra, în capitolul 9, versetul 4, citim aceste cuvinte: Atunci s-au adunat la mine toți cei ce se temeau de cuvintele Dumnezeului lui Israel.

Am ținut să subliniez aceste aspecte în raport cu sfaturile, cu îndemnurile și cu poruncile lui Dumnezeu, pentru că trăim într-un timp, trăim într-o epocă, în care orice autoritate tinde să fie dizolvată de cei care trebuie şi sunt obligați să i se supună. Autoritatea părinţilor este pusă în discuție de copii; tata nu mai este icoana lui Dumnezeu în familie; copiii nu li se mai adresează părinților cu dumneata, ci le spun mă, tu sau hei și nu există respect în casă; părinții au fost coborâți la nivelul copiilor, iar acolo unde copilul este răsfățat peste măsură, autoritatea părinților este anulată complet, așa încât părinții nu mai reprezintă expresia autorității în familie. Ba mai mult, tindem spre înlăturarea oricărei forme de pedeapsă corporală. Mai nou, copiii au dreptul să-și de-a părinții în judecată pentru că au strigat la ei sau pentru că i-au pedepsit în vreun fel, măcar că în Sfânta Scriptură sunt scrise cuvintele: Cine cruță toiagul său iş̦i urăște copilul, iar cel care îl iubește îl ceartă la vreme (Pilde 13, 24). Copilul nu trebuie omorât în bătaie, maltratat sau abuzat fizic, însă lovindu-1 cu nuiaua tu îi scoți sufletul din locuința morților.

Autoritatea dascălilor, a educatorilor, a învățătorilor și a profesorilor este pusă serios sub semnul întrebării. Au trecut vremurile în care profesorul de matematică te trântea cu capul de tablă pentru că nu știai tabla înmulțirii și timpul în care în școli exista 
așa-numitul comitet de disciplină care aplica elevilor tot felul de pedepse pentru disciplinarea lor.

Astăzi este serios diminuată autoritatea forurilor conducătoare ale statului investite cu autoritate. Că ele nu-și onorează oficiul pe care-l ocupă temporar, asta e altă problemă. Să nu mai spunem că s-a mers până acolo încât și autoritatea lui Dumnezeu este pusă în discuție de oameni. Jurăm pe Biblie în diferite ocazii, dar nu cunoaștem conținutul ei și nici poruncile lui Dumnezeu. Tot mai puţin se vorbește despre un Dumnezeu aspru; tot mai rar, sau aproape deloc, se vorbește despre judecata lui Dumnezeu, cu toate că Îi cerem în timpul Sfintei Liturghii să ne dea un răspuns bun la înfricoșătoarea Lui judecată, crezând și mărturisind în același timp că El va veni a doua oară, întru slavă, să judece viii și morții. Omul se teme de multe lucruri: se teme de încălzirea globală, se teme de terorism, de gripa aviară, de arma biologică, de viruși și de bacterii, dar nu se mai teme de Dumnezeu; nu mai are frică de Dumnezeu. Suntem înclinați să vedem în Dumnezeu un moșneag bun și îngăduitor, Îndelung-răbdător și Mult milostiv, care îngăduie cu ușurință călcarea în picioare a poruncilor Lui. Dumnezeu e un Părinte bun care are răbdare să aștepte după comoditatea păcătoșilor, Care așteaptă să le vină mintea la cap, un Dumnezeu extrem de îngăduitor, imagine susținută, fără îndoială, și de textul sfânt.

Dumnezeu este consecvent cu propriile Lui porunci şi cu propriile Sale cuvinte. Iată de pildă, citim în 1 Regi capitolul 15 despre războiul pe care Saul, primul rege al Evreilor, 1-a dus cu Amaleciții. Proorocul Samuel i-a poruncit lui Saul și i-a zis: Du-te și lovește-l pe Amalec și pe Ierim și toate ale lui, și nimic din cele ale lui să nu cruți; ci să-l nimicești și să-l dai pierzării, pe el și toate ale lui: bărbați, femei, copii, animale!. Și Saul s-a dus, 1-a înfrânt pe Amalec, dar n-a respectat legea anatemei și a păstrat, spune textul biblic, ceea ce era mai bun din turme și din cirezi și din poame și din vii și din toate bunătățile, nevrând să le nimicească (1 Regi 15, 9). Saul s-a gândit că Dumnezeu îl va ierta pentru acest gest, iar în eventualitatea că Se va supăra, se gândea că Îl va îmbuna prin jertfe! 
Şi Samuel i-a zis: Oare mai mult Ii plac Domnului arderile-de-tot și jertfele decât 'ascultarea' de cuvântul Său? Iată, 'ascultarea' e mai bună decât o jertfă bună și plinirea poruncii decât grăsimea de berbec ... Și de vreme ce tu ai lepădat cuvântul Domnului, și Domnul te va lepăda pe tine, să nu mai fii rege peste Israel (1 Regi 15, 2223).

Trebuie să ascultăm cuvântul Domnului pentru că e logic, e rațional, e normal să facem acest lucru. Cele mai multe versete din Cartea Pildelor lui Solomon sunt adresate tinerilor; de foarte multe ori apare expresia: Ascultă, fiule! $!^{32}$ sau Fiule, păzește-mi cuvintele; Fiule, cinstește-L pe Domnul; capitole întregi (capitolul 5, capitolul 7) sunt adresate tinerilor, pentru că adolescența și tinerețea reprezintă perioada de timp în care se formează personalitatea omului, se clădește ființa în esența ei, se zidește omul lăuntric.

Dacă ar fi să comparăm tinerețea cu o lucrare - să zicem cu cea a olarului - atunci putem spune că perioada copilăriei și tinerețea corespund momentului în care lutul, pumnul acesta de humă, ajunge pe roata olarului; tinerețea reprezintă, în logica metaforei, momentul în care lutul este pe roată și mâinile Olarului îi dau sau îi plămădesc o formă. Câtă vreme vasul se află pe roată nicio altă mână - în afară de cea a Olarului, a Meșterului, a Artizanului - nu are voie să-l atingă! După ce vasul este introdus în cuptor la o temperatură înaltă și se călește și se întărește, numai atunci poate fi atins. Cam așa este și tinerețea. E bine să stea sub semnul învățăturii sănătoase, sub semnul ascultării și a perseverării în învățătura sănătoasă. Un proverb românesc zice: Spune-mi cu cine te insoțești, ca să-ți spun cine ești. Noi l-am putea parafraza acum și să zicem: Spune-mi ce-ai invățat, spune-mi ce citești și-ți voi spune ce vei deveni sau ce vei fi. Iată de ce Cartea Pildelor ne spune să ne alegem bine prietenii, să ne alegem atent lucrurile cu care venim în părtășie și de la care învățăm.

\footnotetext{
S. Pinto, "Ascolta figlio". Autorità e antropologia dell'insegnamento in Proverbi 1-9. Roma, Città Nuova Editrice, 2006; M. Signoretto, Metafora e didattica in Proverbi 1-9, Assisi 2006.
} 
Copacii mari, brazii din zonele montane, $\mathrm{n}$-au nicio problemă cu vântul puternic și cu viscolul, însă copăcelul, pomul sau copacul tânăr, câtă vreme este răsad are nevoie de susținere ca să-l țină în picioare atunci când bate vântul; are nevoie de un țăruș drept, înfipt lângă el, ca să-l țină drept până se formează, până-i cresc rădăcinile și până ce-și întărește tulpina. În Pilde 22,6 se spune așa: Învață-l pe copil, când este mic, calea pe care trebuie s-o urmeze, și când va imbătrâni nu se va abate de la ea.

Dacă Revelația biblică ne-a oferit întrebarea Prin ce iș̦i va indrepta un tânăr calea sa ?, tot ea ne oferă și răspunsul cel mai potrivit: prin păzirea cuvintelor Domnului (Psalmul 118, 9b).

\section{Bibliografie}

1. *** Biblia sau Sfânta Scriptură. Versiunea diortosită după Septuaginta, redactată și adnotată de Bartolomeu Valeriu Anania, Arhiepiscopul Clujului. București, Editura Institutului Biblic și de Misiune al Bisericii Ortodoxe Române, 2001.

2. *** Dizionario di Teologia Biblica. Edizione italiana a cura del prof. Viola Giovanni. Torino, Marietti, 1965.

3. *** I Profeti. Traduzione e commento di L. Alonso Schökel e J. L. Sicre Diaz, Edizione italiana a cura di Gianfranco Ravasi, Terza Edizione, Roma, Edizioni Borla, 1996.

4. *** L'Antico Testamento. Conoscerlo, leggerlo, viverlo. A cura di Gianfranco Ravasi, Milano, Edizioni San Paolo, 2013.

5. *** Nuovo Dizionario di Teologia Biblica. A cura di Pietro Rossano, Gianfranco Ravasi, Antonio Girlanda. Milano, Edizioni San Paolo, 2005.

6. Bernhard, Lang, Wisdom and the Book of Proverbs. Michigan, Pilgrim Press, 1986.

7. Cantalamessa, Raniero, La tua Parola mi fa vivere. Milano, Àncora Editrice, 2008.

8. Costacurta, Bruna, Corso di Scritti Sapienziali e Salmi. Roma, Pontificia Università Gregoriana, 1998.

9. Gilbert, M., Aletti, J. N., La sapienza e Gesù Cristo, Torino, 1982.

10. Gilbert, Maurice, La Sapienza del cielo, Milano, Cinisello Balsamo, 2005. 
11. Larcher, Chrysostome, Études sur le Livre de la Sagesse. Paris, Gabalda, 1969.

12. Lemaire, André, Le scuole e la formazione della Bibbia nell'Israele antico. Brescia, Paideia Editrice, 1981.

13. Libro dei Proverbi. Tradizione, redazione, teologia. A cura di G. Bellia, A. Passaro. Casale Monferrato, Edizione Piemme, 1999.

14. Mihăilă, Alexandru, (Ne)Lămuriri din Vechiul Testament. Mici comentarii la mari texte, vol. 1. București, Editura Nemira, 2011.

15. Murphy, R. E., L'albero della vita. Una esplorazione della letteratura sapienziale biblica. Brescia, Editrice Queriniana, 1993.

16. Niccacci, Alviero, La casa della sapienza. Voci e volti della sapienza biblica. Milano, Edizioni Paoline, 1994.

17. Pinto, S., Ascolta figlio. Autorità e antropologia dell'insegnamento in Proverbi 1-9. Roma, Città Nuova Editrice, 2006.

18. Pinto, S., Proverbi. Introduzione, traduzione e commento (Nuova versione della Bibbia dai testi antichi, 20). Milano, Edizioni San Paolo, 2013.

19. Rad, Gerhard von, La sapienza in Israele. Torino, Marietti, 1975.

20. Signoretto, M., Metafora e didattica in Proverbi 1-9. Assisi, Cittadella Editrice, 2006. 